\title{
FAKTOR-FAKTOR YANG BERHUBUNGAN DENGAN PEMILIHAN ALAT KONTRASEPSI DALAM RAHIM (AKDR) BAGI AKSEPTOR KB DI PUSKESMAS JAILOLO
}

\author{
Johana D. Bernadus \\ Agnes Madianung \\ Gresty Masi \\ Program Studi Ilmu Keperawatan Fakultas Kedokteran \\ Universitas Sam Ratulangi Manado \\ Email: Bernadusdiana@yahoo.com
}

\begin{abstract}
One strategy of the implementation of the family planning program stated in the Medium Term Development Plan in 2004-2009 was the increasing use of the long-term contraceptive method (LTM) such as the intra uterine device (IUD). IUD is one type of long term contraceptives that is ideal in order to space pregnancies. This study aimed to determine the factors associated with the selections of IUDs for family planning acceptors in Jailolo Health Center. This was a cross sectional design. The population was all active family planning acceptors in Jailolo Health Center. Sampling was done by using simple random sampling. Data were processed by using univariate, bivariate, and multivariate tests, analyzed with SPSS Ver.20 and chi-square with a significance of $\alpha=0.05$. The results showed that based on the bivariate analysis there was a relationship between the variables of age, education, knowledge, service rates, partner approval, and culture with the selection of IUD; while job, economic status, and service rates showed no relationship with the selection of an IUD at the Jailolo Health Center. Multivariate analysis of five related independent variables showed that education was the most dominant in the selection of IUD with $P=0.161$. Conclusion: among the active family planning acceptors in Jailolo Health Center from December 27, 2012 until January 19, 2013, age, education, knowledge, service rate, partner approval, and culture were related to the selections of IUDs; and education was the most dominant one.
\end{abstract}

Keywords: factors, selection of IUD.

\begin{abstract}
Abstrak: Salah satu strategi pelaksanaan program KB seperti tercantum dalam Rencana Pembangunan Jangka Menengah (RPJM) tahun 2004-2009 ialah meningkatnya penggunaan Metode Kontrasepsi Jangka Panjang (MKJP) seperti IUD (Intra Uterine Device, Alat Kontrasepsi Dalam Rahim, AKDR). AKDR merupakan salah satu jenis alat kontrasepsi jangka panjang yang ideal dalam upaya menjarangkan kehamilan. Penelitian ini bertujuan untuk mengetahui faktor-faktor yang berhubungan dengan pemilihan AKDR oleh akseptor KB di Puskesmas Jailolo. Desain penelitian dengan menggunakan cross sectional. Populasi ialah seluruh akseptor KB aktif di Puskesmas Jailolo 27 Desember 2012 sampai dengan 19 Januari 2013. Pengambilan sampel dilakukan dengan simple random sampling. Data diolah secara univariat, bivariat dan multivariat menggunakan SPSS Ver.20 dengan uji Chi-Square dan kemaknaan $\boldsymbol{\alpha}=0,05$. Dari hasil analisis bivariat terdapat hubungan antara variabel usia, pendidikan, pengetahuan, tarif pelayanan, persetujuan pasangan, budaya dengan pemilihan AKDR di Puskesmas Jailolo sedangkan pekerjaan, ekonomi dan tarif pelayanan tidak berhubungan. Hasil analisis multivariat dari lima variabel independen yang berhubungan menunjukkan bahwa pendidikan yang paling dominan dalam pemilihan AKDR dengan nilai $P$ = 0,161. Simpulan: pada akseptor KB aktif di Puskesmas Jailolo 27 Desember 2012 - 19
\end{abstract}


Januari 2013, faktor usia, pendidikan, pengetahuan, tarif pelayanan, persetujuan pasangan, dan budaya mempunyai hubungan dengan pemilihan AKD; dan yang paling berperan ialah faktor pendidikan.

Kata Kunci: Faktor-faktor, Pemilihan AKDR.

Indonesia merupakan salah satu negara berkembang dengan berbagai jenis masalah, salah satunya yaitu dibidang kependudukan. Jumlah penduduk Indonesia sekarang 259 juta jiwa, ${ }^{1}$ dengan pertumbuhan penduduk berkisar antara 2,15\% pertahun hingga 2,49\% per-tahun. Tingkat pertumbuhan penduduk seperti ini dipengaruhi oleh tiga faktor utama yaitu kelahiran (Fertilitas), kematian (Mortalitas), perpindahan penduduk (Migrasi). ${ }^{2}$

Upaya pemerintah untuk menekan laju pertumbuhan penduduk dengan salah satu program Keluarga Berencana (KB). ${ }^{3}$ Salah satu strategi dari pelaksanaan program $\mathrm{KB}$ sendiri seperti tercantum dalam Rencana Pembangunan Jangka Menengah (RPJM) tahun 2004-2009 ialah meningkatnya penggunaan metode kontrasepsi jangka panjang (MKJP). Keuntungan pemakaian IUD yakni hanya memerlukan satu kali pemasangan untuk jangka waktu yang lama dengan biaya yang relatif murah, aman karena tidak mempunyai pengaruh sistemik yang beredar ke seluruh tubuh, tidak mempengaruhi produksi ASI dan kesuburan cepat kembali setelah IUD dilepas.

Beberapa faktor yang dapat mempengaruhi seorang ibu dalam memilih alat kontrasepsi dalam rahim, diantaranya: tingkat pendidikan, pengetahuan, ekonomi, tarif pelayanan, persetujuan pasangan, budaya oleh karena itu tenaga kesehatan diharapkan mampu memberikan Komunikasi Informasi dan Edukasi (KIE) yang lebih efektif kepada calon akseptor KB. ${ }^{3}$

Berdasarkan data awal Dinas Kesehatan kabupaten Halmahera Barat tahun 2010 peserta KB pil 20.080, suntik 4.372, implan 1.461, IUD 121, Metode Operatif Wanita (MOW) 109, Metode Operatif Pria (MOP) 9, kondom 66. Pada tahun 2011 peserta KB suntik 6.328, implan 2.150, IUD 582, MOW 115, MOP 6, dan kondom 63. Data di Puskesmas Jailolo tahun 2011 memperlihatkan jumlah akseptor KB suntik 269, implan 462, IUD 272, pil 96, vasektomi 5, dan kondom 23. Pada tahun 2012 jumlah akseptor KB suntik 517, IUD 398, implan 269, pil 111, MOW 16, dan kondom 7. Meningkatnya akseptor KB IUD menandakan bahwa terdapatnya minat akseptor terhadap kontrasepsi ini.

\section{METODE PENELITIAN}

Penelitian ini merupakan penelitian analitik dengan rancangan cross sectional dimana observasi atau pengukuran variabel sekali dan sekaligus pada waktu yang sama. ${ }^{4}$ Populasi ialah seluruh akseptor KB aktif di Puskesmas Jailolo dari Oktober s/d Desember 2012 yang berjumlah 1318 akseptor. Sampel ialah akseptor KB yang berjumlah 96 responden di Puskesmas Jailolo. Penelitian dilaksanakan di Puskesmas Jailolo sejak tanggal 27 Desember 2012 sampai dengan 19 Januari 2013.

Pengambilan sampel dengan menggunakan rumus:

$$
n=\frac{z_{(1-\alpha / 2)}{ }^{2} \mathrm{P}(1-\mathrm{P})}{d^{2}}
$$

Ket. $\mathrm{n}=$ Besar sampel. $\mathrm{Z}\left(1-\frac{\alpha}{2}\right)=$ nilai sebaran normal baku, besarnya tergantung tingkat kepercayaan (TK). TK 95\%=1,96. P=Proporsi populasi, jika tidak diketahui dianjurkan 0,5. $d=$ besar penyimpangan: 0,1

Besar sampel berdasarkan perhitungan diatas adalah :

$n=\frac{(1,96)^{2}(0,5)(1-0,5)}{(0,1)^{2}}=96$ orang

Dalam penelitian ini tehnik pengambilan sampel dilakukan dengan cara simple random sampling. ${ }^{5}$ Sampel diambil secara acak pada empat desa dengan jumlah populasi 379 dan yang akan dijadikan 
responden 96 orang. Tehnik pengambilan sampel yaitu dengan memberikan kode secara berurutan pada populasi dari nomor 1 s/d 95 kemudian sampel diambil nomor satu dan seterusnya urutan kelipatan empat sehingga didapatkan 24 responden/desa.

Instrumen penelitian berupa kuesioner tentang pengetahuan, ekonomi, per-setujuan pasangan, tarif pelayanan, budaya serta karakteristik responden berupa umur, pendidikan, pekerjaan. Kuesioner ini berisi beberapa pertanyaan yang harus dijawab oleh responden. Terdapat 15 pertanyaan tentang pengetahuan dengan menggunakan skala Liker.

Jawaban responden dengan skor tertinggi $5 \times 15=75$ dan skor terendah $1 \times 15=$ 15. Nilai ini diurutkan sehingga diperoleh nilai median 45 . Kriteria objektif pengetahuan responden: Baik, jika respon-den mampu menjawab pertanyaan dalam kuesioner $>45$ dari 15 pertanyaan; dan Kurang, jika responden mampu menjawab pertanyaan dalam kuesioner $\leq 45$ dari 15 pertanyaan.

Analisis hubungan menggunakan uji statistik dengan rumus sebagai berikut:

$$
X^{2}=E \frac{(O-E)^{2}}{E}
$$

Ket: $\mathrm{X}^{2}=$ Chi Kuadrat. $\mathrm{O}=$ Nilai Observasi (ObservationValue). $\mathrm{E}=$ Nilai Harapan (Expected Value).

\section{HASIL PENELITIAN}

\section{Analisis univariat}

\section{Karakteristik responden}

Tabel 1 menunjukkan usia responden dewasa muda ( $>20$ tahun) berjumlah 77 orang $(80,2 \%)$ dan usia muda $(<20$ tahun) berjumlah 19 orang (19,8\%). Pendidikan tinggi berjumlah 72 orang $(75,0 \%)$ dan pendidikan rendah berjumlah 24 orang (25,0\%). Responden yang tidak bekerja berjumlah 52 orang (54,2\%) sedangkan yang bekerja berjumlah 44 orang $(45,8 \%)$.
Tabel 1. Distribusi frekuensi berdasarkan karakteristik responden di Puskesmas Jailolo

\begin{tabular}{lcc}
\hline Karakteristik & Frekuensi & $\mathbf{\%}$ \\
\hline Usia & & \\
$\quad<20$ tahun & 19 & 19,8 \\
$>20$ tahun & 77 & 80,2 \\
\hline Pendidikan & & \\
Rendah & 24 & 25,0 \\
Tinggi & 72 & 75,0 \\
\hline Pekerjaan & & \\
Tidak Bekerja & 52 & 54,2 \\
Bekerja & 44 & 45,8 \\
\hline
\end{tabular}

\section{Faktor-faktor}

Tabel 2 menunjukkan responden dengan pengetahuan baik berjumlah 54 orang (56,3\%) dan pengetahuan kurang berjumlah 42 orang $(43,8 \%)$.

Tabel 2. Distribusi frekuensi berdasarkan tingkat pengetahuan responden di Puskesmas Jailolo.

\begin{tabular}{ccc}
\hline Pengetahuan & Frekuensi & $\%$ \\
\hline Baik & 54 & 56,3 \\
Kurang & 42 & 43,8 \\
Jumlah & 96 & 100 \\
\hline
\end{tabular}

Tabel 3 menunjukkan responden dengan tingkat ekonomi rendah berjumlah 54 orang $(56,3 \%)$ dan tingkat ekonomi tinggi berjumlah 42 orang (43,8\%).

Tabel 3. Distribusi frekuensi berdasarkan tingkat ekonomi responden di Puskesmas Jailolo.

\begin{tabular}{lcc}
\hline Tingkat Ekonomi & Frekuensi & $\%$ \\
\hline $\begin{array}{l}\text { Rendah } \\
(<\text { Rp. 960.000) }\end{array}$ & 54 & 56,3 \\
$\begin{array}{l}\text { Tinggi } \\
\text { (>Rp. 960.000) } \\
\text { Jumlah }\end{array}$ & 42 & 43,8 \\
\hline
\end{tabular}

Tabel 4 menunjukkan tarif pelayanan mahal berjumlah 54 orang (56,3\%) dan tarif pelayanan murah berjumlah 42 orang $(43,8 \%)$ 
Tabel 4. Distribusi frekuensi berdasarkan tarif pelayanan responden di Puskesmas Jailolo.

\begin{tabular}{lcc}
\hline Tarif Pelayanan & Frekuensi & $\%$ \\
Murah & 42 & 43,8 \\
Mahal & 54 & 56,3 \\
Jumlah & 96 & 100 \\
\hline
\end{tabular}

Tabel 5 menunjukkan responden dengan persetujuan pasangan yang mendukung berjumlah 58 orang $(60,4 \%)$ dan persetujuan pasangan yang tidak mendukung berjumlah 38 orang (39,6\%).

Tabel 5. Distribusi frekuensi berdasarkan persetujuan pasangan responden di Puskesmas Jailolo.

\begin{tabular}{ccc}
\hline $\begin{array}{c}\text { Persetujuan } \\
\text { pasangan }\end{array}$ & Frekuensi & $\%$ \\
\hline Tidak mendukung & 38 & 39,6 \\
Mendukung & 58 & 60,4 \\
$\quad$ Jumlah & 96 & 100 \\
\hline
\end{tabular}

Berdasarkan Tabel 6, budaya yang tidak melarang berjumlah 61 orang $(63,5 \%)$ sedangkan budaya yang melarang berjumlah 35 orang (36,5\%).

Tabel 6. Distribusi frekuensi berdasarkan budaya responden di Puskesmas Jailolo.

\begin{tabular}{ccc}
\hline Budaya & Frekuensi & Persen \\
\hline Melarang & 35 & 36,5 \\
Tidak & 61 & 63,5 \\
Jumlah & 96 & 100 \\
\hline
\end{tabular}

Berdasarkan Tabel 7, pemilihan responden non AKDR berjumlah 60 orang (62,5\%) sedangkan AKDR berjumlah 36 orang $(37,5 \%)$.

Tabel 7. Distribusi frekuensi berdasarkan pemilihan AKDR dan Non AKDR.

\begin{tabular}{ccc}
\hline Pemilihan & Frekuensi & $\%$ \\
\hline AKDR & 36 & 37,5 \\
Non AKDR & 60 & 62,5 \\
Jumlah & 96 & 100 \\
\hline
\end{tabular}

\section{Analisis Bivariat}

\section{Hubungan usia dengan pemilihan AKDR}

Responden dengan usia dewasa muda (>20 tahun) berjumlah 77 orang, yang memilih AKDR sebanyak 36 (37,5\%) dan non AKDR sebanyak 41 (53,2\%), sedangkan responden dengan usia muda $(<20$ tahun) berjumlah 19 orang, yang memilih AKDR 0 (0,0\%) dan non AKDR berjumlah 19 orang (100\%). Berdasarkan hasil uji chisquare didapatkan nilai $P=0,000$ yang berarti lebih kecil dari $\boldsymbol{\alpha}=0,05$; dengan demikian dapat dikatakan bahwa terdapat hubungan yang bermakna antara usia dengan pemilihan AKDR bagi akseptor KB (Tabel 8).

Odds Ratio (OR) 1,878 menunjukkan bahwa responden berusia dewasa muda (>20 tahun) dalam pemilihan kontrasepsi 1,878 kali mempunyai peluang dalam pemilihan AKDR.

Tabel 9 menunjukkan bahwa responden dengan pendidikan tinggi berjumlah 72 orang yang memilih AKDR sebanyak 34 (47,2\%) dan non AKDR 38 orang (52,8\%); sedangkan responden dengan pendidikan rendah berjumlah 24 orang yang memilih AKDR dua orang $(8,3 \%)$ dan non AKDR 22 orang $(91,7 \%)$. Berdasarkan hasil uji chi-square didapatkan nilai $P=0,002$ yang berarti lebih kecil dari $\boldsymbol{\alpha}=0,05$; dengan demikian dapat dikatakan bahwa terdapat hubungan yang bermakna antara pendidikan dengan pemilihan AKDR bagi akseptor KB. OR 0,102 menunjukkan bahwa responden dengan pendidikan tinggi 0,102 kali lebih berpeluang dalam pemilihan AKDR.

Tabel 10 menunjukkan dari responden tidak bekerja berjumlah 52 orang, yang memilih AKDR berjumlah 15 orang (28,8\%) sedangkan non AKDR berjumlah 37 orang (71,2\%); dan dari responden yang bekerja berjumlah 44 orang, yang memilih AKDR berjumlah 21 orang (47,7\%) sedangkan non AKDR berjumlah 23 (52,3\%). Berdasarkan hasil uji chi-square didapatkan niali $P=0,091$ yang berarti lebih besar dari $\boldsymbol{\alpha}=0,05$; dengan demikian tidak terdapat hubungan antara pekerjaan dengan pemilihan AKDR bagi akseptor KB. 
Tabel 8. Hubungan usia dengan pemilihan AKDR bagi akseptor KB di Puskesmas Jailolo.

\begin{tabular}{|c|c|c|c|c|c|c|c|c|}
\hline \multirow{3}{*}{ Usia } & \multicolumn{4}{|c|}{ Pemilihan } & \multirow{2}{*}{\multicolumn{2}{|c|}{ Total }} & \multirow{3}{*}{$\begin{array}{c}\mathrm{P} \\
\text { Value }\end{array}$} & \multirow{3}{*}{ OR } \\
\hline & \multicolumn{2}{|c|}{ AKDR } & \multicolumn{2}{|c|}{ Non AKDR } & & & & \\
\hline & $\mathrm{n}$ & $\%$ & $\mathrm{n}$ & $\%$ & $\mathrm{n}$ & $\%$ & & \\
\hline$<20$ tahun & 0 & 0,0 & 19 & 100 & 19 & 100 & \multirow{3}{*}{0,000} & \multirow{3}{*}{1,878} \\
\hline$>20$ tahun & 36 & 46,8 & 41 & 53,2 & 77 & 100 & & \\
\hline Jumlah & 36 & 37,5 & 60 & 62,5 & 96 & 100 & & \\
\hline
\end{tabular}

Tabel 9. Hubungan pendidikan dengan pemilihan AKDR bagi akseptor KB di Puskesmas Jailolo.

\begin{tabular}{|c|c|c|c|c|c|c|c|c|}
\hline \multirow{3}{*}{ Pendidikan } & \multicolumn{4}{|c|}{ Pemilihan } & \multirow{2}{*}{\multicolumn{2}{|c|}{ Total }} & \multirow{3}{*}{$\begin{array}{c}\mathrm{P} \\
\text { Value }\end{array}$} & \multirow{3}{*}{ OR } \\
\hline & \multicolumn{2}{|c|}{ AKDR } & \multicolumn{2}{|c|}{ Non AKDR } & & & & \\
\hline & $\mathrm{n}$ & $\%$ & $\mathrm{n}$ & $\%$ & $\mathrm{n}$ & $\%$ & & \\
\hline Rendah & 2 & 8,3 & 22 & 91,7 & 24 & 100 & \multirow{3}{*}{0.002} & \multirow{3}{*}{0,102} \\
\hline Tinggi & 34 & 47,2 & 38 & 52,8 & 72 & 100 & & \\
\hline Jumlah & 36 & 37,5 & 60 & 62,5 & 96 & 100 & & \\
\hline
\end{tabular}

Tabel 10. Hubungan pekerjaan dengan pemilihan AKDR bagi akseptor KB.

\begin{tabular}{|c|c|c|c|c|c|c|c|c|}
\hline \multirow{3}{*}{ Pekerjaan } & \multicolumn{4}{|c|}{ Pemilihan } & \multirow{2}{*}{\multicolumn{2}{|c|}{ Total }} & \multirow{3}{*}{$\begin{array}{c}\mathrm{P} \\
\text { Value }\end{array}$} & \multirow{3}{*}{ OR } \\
\hline & \multicolumn{2}{|c|}{ AKDR } & \multicolumn{2}{|c|}{ Non AKDR } & & & & \\
\hline & $\mathrm{n}$ & $\%$ & $\mathrm{n}$ & $\%$ & $\mathrm{n}$ & $\%$ & & \\
\hline Tidak bekerja & 15 & 28,8 & 37 & 71,2 & 52 & 100 & \multirow{3}{*}{0,091} & \multirow{3}{*}{0,444} \\
\hline Bekerja & 21 & 47,7 & 23 & 52,3 & 44 & 100 & & \\
\hline Jumlah & 36 & 37,5 & 60 & 62,5 & 96 & 100 & & \\
\hline
\end{tabular}

Tabel 11. Hubungan pengetahuan dengan pemilihan AKDR bagi akseptor KB.

\begin{tabular}{|c|c|c|c|c|c|c|c|c|}
\hline \multirow{3}{*}{ Pengetahuan } & \multicolumn{4}{|c|}{ Pemilihan } & \multirow{2}{*}{\multicolumn{2}{|c|}{ Total }} & \multirow{3}{*}{$\begin{array}{c}\mathrm{P} \\
\text { Value }\end{array}$} & \multirow{3}{*}{ OR } \\
\hline & \multicolumn{2}{|c|}{ AKDR } & \multicolumn{2}{|c|}{ Non AKDR } & & & & \\
\hline & $\mathrm{n}$ & $\%$ & $\mathrm{n}$ & $\%$ & $\mathrm{n}$ & $\%$ & & \\
\hline Baik & 26 & 48,1 & 28 & 51,9 & 54 & 100 & \multirow{3}{*}{0,026} & \multirow{3}{*}{2,971} \\
\hline Kurang & 10 & 23,8 & 32 & 52,3 & 42 & 100 & & \\
\hline Jumlah & 36 & 37,5 & 60 & 62,5 & 96 & 100 & & \\
\hline
\end{tabular}

Tabel 12. Hubungan tingkat ekonomi dengan pemilihan AKDR bagi akseptor KB.

\begin{tabular}{|c|c|c|c|c|c|c|c|c|}
\hline \multirow{3}{*}{ Ekonomi } & \multicolumn{4}{|c|}{ Pemilihan } & \multirow{2}{*}{\multicolumn{2}{|c|}{ Total }} & \multirow{3}{*}{$\begin{array}{c}\mathrm{P} \\
\text { Value }\end{array}$} & \multirow{3}{*}{ OR } \\
\hline & \multicolumn{2}{|c|}{ AKDR } & \multicolumn{2}{|c|}{ Non AKDR } & & & & \\
\hline & $\mathrm{n}$ & $\%$ & $\mathrm{n}$ & $\%$ & $\mathrm{n}$ & $\%$ & & \\
\hline Rendah & 23 & 42,6 & 31 & 57,4 & 54 & 100 & \multirow{3}{*}{0,339} & \multirow{3}{*}{1,655} \\
\hline Tinggi & 13 & 31,0 & 29 & 69,0 & 42 & 100 & & \\
\hline Jumlah & 36 & 37,5 & 60 & 62,5 & 96 & 100 & & \\
\hline
\end{tabular}


Berdasarkan Tabel 11, responden dengan pengetahuan baik berjumlah 54 orang, yang memilih AKDR berjumlah 26 orang (48,1\%) sedangkan non AKDR berjumlah 28 orang (51,9\%); dan pengetahuan kurang berjumlah 42 orang, yang memilih AKDR berjumlah 10 orang (23,8\%) sedangkan yang non AKDR berjumlah 32 orang (52,3\%). Berdasarkan hasil uji chi-square didapatkan nilai $P=0,026$ yang berarti lebih kecil dari $\boldsymbol{\alpha}=0,05$; dengan demikian terdapat hubungan antara pengetahuan dengan pemilihan AKDR bagi akseptor KB. OR 2,971 menunjukkan bahwa responden dengan pengetahuan baik 2,971 kali lebih mempunyai peluang memilih AKDR.

Tabel 12 menunjukkan responden dengan tingkat ekonomi rendah berjumlah 54 orang, yang memilih AKDR berjumlah 23 orang (42,6\%) sedangkan non AKDR berjumlah 31 orang (57,4\%). Responden dengan tingkat ekonomi tinggi berjumlah 42 orang, yang memilih AKDR 13 orang (31,0\%) sedangkan non AKDR 29 orang (69,0\%). Berdasarkan hasil uji chi-square didapatkan nilai $P=0,339$ yang berarti lebih besar dari $\boldsymbol{\alpha}=0,05$; dengan demikian tidak terdapat hubungan antara status ekonomi dengan pemilihan AKDR bagi akseptor KB.
Tabel 13 menunjukkan tarif pelayanan mahal berjumlah 54 orang, responden yang memilih AKDR berjumlah 17 orang (31,5\%) sedangkan non AKDR sebanyak 37 orang (68,5\%). Tarif pelayanan murah berjumlah 42 orang, responden yang memilih AKDR berjumlah 19 orang (45,2\%) sedangkan non AKDR berjumlah 23 orang (54,8\%). Berdasarkan hasil uji chi-square didapatkan nilai $P=0,243$ yang berarti lebih besar dari $\boldsymbol{\alpha}=0,05$; dengan demikian tidak terdapat hubungan antara tarif pelayanan dan pemilihan AKDR bagi akseptor KB.

Tabel 14 menunjukkan persetujuan pasangan yang mendukung berjumlah 58 orang, responden yang memilih AKDR berjumlah 27 orang (46,6\%) sedangkan non AKDR 31 orang $(53,4 \%)$. Dari persetujuan pasangan tidak mendukung berjumlah 38 orang, responden yang memilih AKDR sembilan orang $(23,7 \%)$ sedangkan non AKDR berjumlah 29 orang (76,3\%). Berdasarkan hasil uji statistik chi-Square nilai $P=0,041$ lebih kecil dari $\boldsymbol{\alpha}(0,05)$; dengan demikian dapat dikatakan bahwa terdapat hubungan persetujuan pasangan dengan pemilihan AKDR di Puskesmas Jailolo.

Tabel 13. Hubungan tarif pelayanan dengan pemilihan AKDR bagi akseptor KB.

\begin{tabular}{|c|c|c|c|c|c|c|c|c|}
\hline \multirow{3}{*}{$\begin{array}{c}\text { Tarif } \\
\text { pelayanan }\end{array}$} & \multicolumn{4}{|c|}{ Pemilihan } & \multirow{2}{*}{\multicolumn{2}{|c|}{ Total }} & \multirow{3}{*}{$\begin{array}{c}\mathrm{P} \\
\text { Value }\end{array}$} & \multirow{3}{*}{ OR } \\
\hline & \multicolumn{2}{|c|}{ AKDR } & \multicolumn{2}{|c|}{ Non AKDR } & & & & \\
\hline & $\mathrm{n}$ & $\%$ & $\mathrm{n}$ & $\%$ & $\mathrm{n}$ & $\%$ & & \\
\hline Murah & 19 & 45,2 & 23 & 54,8 & 42 & 100 & & \\
\hline Mahal & 17 & 31,5 & 37 & 68,5 & 54 & 100 & 0,243 & 1,798 \\
\hline Jumlah & 36 & 37,5 & 60 & 62,5 & 96 & 100 & & \\
\hline
\end{tabular}

Tabel 14. Hubungan persetujuan pasangan dengan pemilihan AKDR bagi akseptor KB

\begin{tabular}{|c|c|c|c|c|c|c|c|c|}
\hline \multirow{3}{*}{$\begin{array}{c}\text { Persetujuan } \\
\text { Pasangan }\end{array}$} & \multicolumn{4}{|c|}{ Pemilihan } & \multirow{2}{*}{\multicolumn{2}{|c|}{ Total }} & \multirow{3}{*}{$\begin{array}{c}\mathrm{P} \\
\text { Value }\end{array}$} & \multirow{3}{*}{ OR } \\
\hline & \multicolumn{2}{|c|}{ AKDR } & \multicolumn{2}{|c|}{$\begin{array}{c}\text { Non } \\
\text { AKDR }\end{array}$} & & & & \\
\hline & $\mathrm{n}$ & $\%$ & $\mathrm{~N}$ & $\%$ & $\mathrm{n}$ & $\%$ & & \\
\hline Tidak & & & & & & & & \\
\hline Mendukung & 9 & 23,7 & 29 & 76,3 & 38 & 100 & & \\
\hline Mendukung & 27 & 46,6 & 31 & 53,4 & 58 & 100 & 0,041 & 0,356 \\
\hline Jumlah & 36 & 37,5 & 60 & 62,5 & 96 & 100 & & \\
\hline
\end{tabular}


Tabel 15. Hubungan budaya dengan pemilihan AKDR bagi Puskesmas Jailolo.

\begin{tabular}{|c|c|c|c|c|c|c|c|c|}
\hline \multirow{3}{*}{ Budaya } & \multicolumn{4}{|c|}{ Pemilihan } & \multirow{2}{*}{\multicolumn{2}{|c|}{ Total }} & \multirow{3}{*}{$\begin{array}{c}\mathrm{P} \\
\text { Value }\end{array}$} & \multirow{3}{*}{ OR } \\
\hline & \multicolumn{2}{|c|}{ AKDR } & \multicolumn{2}{|c|}{ Non AKDR } & & & & \\
\hline & $\mathrm{n}$ & $\%$ & $\mathrm{n}$ & $\%$ & $\mathrm{n}$ & $\%$ & & \\
\hline Ya & 7 & 20,0 & 28 & 80,0 & 35 & 100 & & \\
\hline Tidak & 29 & 47,5 & 32 & 52,5 & 61 & 100 & 0.014 & 0,276 \\
\hline Jumlah & 36 & 37,5 & 60 & 62,5 & 96 & 100 & & \\
\hline
\end{tabular}

Tabel 16. Analisis multivariat faktor-faktor yang berhubungan dengan pemilihan alat kontrasepsi dalam rahim (AKDR) bagi akseptor KB di Puskesmas Jailolo.

\begin{tabular}{lcccc}
\hline \multicolumn{1}{c}{ Variabel } & Koefisien regresi & Wald & Df & P \\
\hline Usia & 0,653 & 0,000 & 1 & 0,998 \\
Pendidikan & 3,465 & 1,998 & 1 & 0,161 \\
Pengetahuan & 0,534 & 1,381 & 1 & 0,240 \\
Persetujuan Pasangan & 1,564 & 0,246 & 1 & 0,620 \\
Budaya & 2,231 & 0,712 & 1 & 0,399 \\
\hline
\end{tabular}

OR 0,356 menunjukkan bahwa responden dengan persetujuan pasangan yang mendukung 0,356 kali mempunyai peluang dalam pemilihan AKDR.

Hasil analisis berdasarkan Tabel 15 menunjukkan budaya tidak melarang memilih AKDR berjumlah 61 orang, yang memilih AKDR berjumlah 29 orang (47,5\%) sedangkan non AKDR 32 orang (52,5\%). Budaya yang melarang berjumlah 35 orang, dan yang memilih AKDR berjumlah tujuh orang (20,0\%) sedangkan non AKDR berjumlah 28 orang (80,0\%). Berdasarkan hasil uji statistik chi-square diperoleh nilai $P=0,014$ lebih kecil dari $\boldsymbol{\alpha}$ $(0,05)$; dengan demikian dapat dikatakan bahwa ada hubungan budaya dengan pemilihan AKDR di Puskesmas Jailolo.

Selanjutnya dari OR 0,276 menunjukkan bahwa responden dengan budaya tidak melarang 0,276 kali lebih mempunyai peluang dalam pemilihan AKDR.

\section{Analisis Multivariat}

Analisa multivariat digunakan untuk melihat faktor yang mempengaruhi pemilihan AKDR. Dari analisa bivariat diperoleh lima variabel independen meliputi umur, pendidikan, pengetahuan, persetujuan pasangan dan budaya yang mem- pengaruhi pemilihan AKDR.

Analisis regresi logistik kelima variabel independen tersebut memperlihatkan yang paling berpengaruh ialah pendidikan dengan nilai $P=0,161$ (Tabel 16). Hal ini menunjukkan bahwa pendidikan lebih berperan dalam pemilihan AKDR.

\section{BAHASAN}

\section{Usia}

Hasil penelitian terhadap 96 sampel, sebagian besar responden berusia dewasa muda ( $>20$ tahun) dalam pemilihan kontrasepsi yaitu 77 orang (Tabel 1). Responden berusia di atas 20 tahun lebih memilih AKDR karena secara fisik kesehatan reproduksi sudah lebih matang dan merupakan tolak ukur tingkat kedewasaan seseorang. Makin bertambahnya usia seseorang dikatakan makin dewasa dalam pikiran dan tingkah laku. Usia di atas 20 tahun merupakan masa menjarangkan dan mencegah kehamilan sehingga pilihan kontrasepsi lebih ditujukan pada kontrasepsi jangka panjang. Responden berusia kurang dari 20 tahun lebih memilih non AKDR karena usia tersebut merupakan masa menunda kehamilan sehingga pilihan kontrasepsi selain dari AKDR yaitu pil, suntikan, implan, dan kontrasepsi sederhana. 
Hasil uji chi-square dengan nilai $P<\boldsymbol{\alpha}$ $(0,05)$ menunjukkan terdapatnya hubungan usia dan pemilihan AKDR bagi akseptor KB di Puskesmas Jailolo. Usia dewasa muda 1,878 kali lebih berpeluang memilih AKDR dari pada usia muda (Tabel 8).

\section{Pendidikan}

Hasil penelitian memperlihatkan responden yang terbanyak berpendidikan tinggi yaitu 72 orang (Tabel 1). Responden dengan pendidikan tinggi terbanyak membuktikan bahwa masyarakat pada umumnya telah menyadari pendidikan merupakan hal penting yang harus diikuti.

Hasil uji chi-square pendidikan responden mendapatkan nilai $P<\boldsymbol{\alpha}(0,05)$, yang menunjukkan bahwa terdapat hubungan antara pendidikan dan pemilihan AKDR bagi akseptor KB (Tabel 9). Tingkat pendidikan tidak saja mempengaruhi kerelaan menggunakan $\mathrm{KB}$ tetapi juga pemilihan suatu metode. ${ }^{3}$ Pada penelitian ini responden dengan pendidikan tinggi 0,102 kali lebih berpeluang dalam memilih AKDR dari pada pendidikan rendah.

\section{Pekerjaan}

Pada penelitian ini sebagian besar responden tidak bekerja, terbanyak ibu rumah tangga, dengan aktivitas sehari-hari di rumah, kebun dan berdagang (Tabel 1).

Berdasarkan hasil uji chi-square untuk pekerjaan didapatkan nilai $P>\boldsymbol{\alpha}(0,05)$, nilai CI 95\%, dan OR 0,444 (Tabel 10). Dengan demikian tidak terdapat hubungan antara pekerjaan dan pemilihan AKDR bagi akseptor KB. Hasil penelitian ini sama dengan penelitian Endang (2007) di RSU Pandan Arang, Boyolali. Bekerja atau tidak bekerja tidak memengaruhi seorang akseptor dalam pemilihan kontrasepsi, khususnya AKDR, sebab kontrasepsi ini tidak mengganggu aktivitas sehari-hari.

\section{Pengetahuan}

Hasil penelitian ini memperlihatkan responden terbanyak dengan pengetahuan baik (Tabel 2). Responden dengan pengetahuan baik membuktikan bahwa pengetahuan tentang AKDR sudah didapat sebelumnya melalui tenaga kesehatan, televisi atau majalah. Menurut Rogers (1974) yang dikutip oleh Notoatmodjo (2007), ${ }^{6}$ seseorang berperi-laku didasari oleh pengetahuan, kesadaran dan sikap positif sehingga perilaku tersebut akan bersifat langgeng, sebaliknya bila perilaku itu tidak didasari pengetahuan dan kesadaran maka tidak akan berlangsung lama.

Berdasarkan hasil uji Chi-Square didapatkan nilai $P<\boldsymbol{\alpha}(0,05)$ (Tabel 11). Dengan demikian terdapat hubungan antara pengetahuan dan pemilihan AKDR bagi akseptor KB. Responden dengan pengetahuan baik 2,971 kali lebih berpeluang memilih AKDR dari pada yang berpengetahuan kurang.

\section{Tingkat ekonomi}

Hasil penelitian terhadap ekonomi responden terbanyak ekonomi rendah (Tabel 3). Responden dengan ekonomi keluarga atau penghasilan di bawah UMR juga memilih AKDR. Kemajuan program KB tidak lepas dari tingkat ekonomi masyarakat karena berkaitan erat dengan kemampuan membeli alat kontrasepsi. Oleh karena itu, BKKBN mengeluarkan peraturan baru yakni pemasangan dan penggunaan kontrasepsi dapat dilakukan secara gratis di Puskesmas.

Berdasarkan hasil uji Chi-Square didapatkan nilai $P>\boldsymbol{\alpha}(0,05)$ sehingga tidak terdapat hubungan antara status ekonomi dan pemilihan AKDR bagi akseptor KB (Tabel 12).

\section{Tarif pelayanan}

Dari hasil penelitian mengenai tarif pelayanan dalam pemilihan kontrasepsi, responden yang terbanyak berpendapat mahal (Tabel 4). Menurut sebagian responden, biaya pemasangan AKDR mahal karena pemasangan dilakukan oleh tenaga kesehatan di tempat praktek; sedangkan responden AKDR terbanyak me- 
ngatakan biaya murah karena pemasangan dilakukan di Puskesmas secara gratis.

Berdasarkan hasil uji chi-square didapatkan niali $P>\boldsymbol{\alpha}(0,05)$, sehingga tidak terdapat hubungan antara tarif pelayanan dan pemilihan AKDR bagi akseptor KB (Tabel 13).

Tarif pelayanan ini berhubungan dengan kemampuan akseptor membayar jasa layanan yang diterima. Bagi akseptor, AKDR tidak menjadi masalah karena responden dengan tingkat pendidikan tinggi dan pengetahuan baik memotivasi responden untuk menggunakan AKDR.

\section{Persetujuan pasangan}

Tingginya dukungan pasangan membuktikan bahwa rata-rata pasangan/ suami responden sudah berpengetahuan baik tentang AKDR (Tabel 5). Teori Lawrence Green mengemukakan bahwa faktor dukungan suami dapat dikatakan sebagai salah satu faktor anteseden (pemungkin), yang memungkinkan suatu motivasi atau aspirasi terlaksana. Perpaduan antara pendidikan, pengetahuan dan dukungan suami dengan kemauan yang kuat dari istri dalam menetapkan pilihan pada alat kontrasepsi yang terbukti efektif tersebut membuahkan keputusan yang bulat bagi kedua pasangan dalam menggunakan kontrasepsi tersebut.

Berdasarkan hasil uji statistik chisquare nilai $P<\boldsymbol{\alpha}(0,05)$ ini menunjukkan bahwa ada hubungan persetujuan pasangan dengan pemilihan AKDR di Puskesmas Jailolo (Tabel 14). Ambarwati mengemukakan bahwa persetujuan pasangan/suami berperan penting dalam pemilihan AKDR. Pemasangan AKDR membutuhkan kerjasama dengan suami karena alasan takut benangnya mengganggu saat bersenggama. ${ }^{3}$ Pada penelitian ini responden dengan persetujuan pasangan yang men-dukung 0,356 kali lebih berpeluang dalam memilih AKDR dari pada pasangan yang tidak mendukung.

\section{Budaya}

Dari hasil penelitian terhadap budaya, responden AKDR terbanyak mengatakan budaya tidak melarang dan tujuh responden mengatakan budaya melarang karena isu yang beredar di tengah masyarakat tentang efek samping pemasangan AKDR yaitu perdarahan lebih lama yang dapat mengganggu ibadah seseorang (Tabel 6). Kebiasaan yang ada dimasyarakat seiring teknologi dan informasi yang berkembang berpengaruh besar dalam mengubah kebiasaan yang dianggap kurang bermanfaat.

Sejumlah faktor budaya mempengaruhi akseptor dalam memilih metode kontrasepsi. Nilai agama merupakan bagian penting dari nilai budaya kelompok yang memiliki satu agama dominan. Nilai agama bila dikaitkan dengan budaya manapun dapat mempengaruhi banyak aspek kehidupan, salah satunya keluarga berencana.

Berdasarkan hasil uji statistik chisquare diperoleh nilai $P<\boldsymbol{\alpha}(0,05)$ yang menunjukkan terdapatnya hubungan bermakna antara budaya dan pemilihan AKDR di Puskesmas Jailolo (Tabel 15). Pada penelitian ini responden dengan budaya yang tidak melarang 0,276 kali lebih berpeluang dalam pemilihan AKDR dari pada budaya yang melarang. Responden dengan mayoritas beragama Islam menyatakan bahwa agama tidak melarang menggunakan kontrasepsi sehinggga akseptor lebih bebas memilih sesuai keinginan.

\section{Faktor dominan yang berhubungan dengan pemilihan AKDR.}

Berdasarkan analisis regresi logistik, kelima variabel independen yaitu umur, pendidikan, pengetahuan, persetujuan pasangan, dan budaya menunjukkan bahwa faktor pendidikan yang lebih dominan berhubungan dalam pemilihan AKDR dengan nilai $P=0,161$ (Tabel 16).

Pendidikan memengaruhi seorang calon akseptor untuk memilih metode kontrasepsi yang digunakan. Semakin tinggi pendidikan semakin tinggi pula pengetahuan yang dimiliki sehingga akseptor dapat mengambil keputusan yang terbaik. Usia dewasa, pengetahuan yang baik, persetujuan pasangan mendukung, dan budaya 
yang tidak melarang dalam pemilihan AKDR perlu didasari pendidikan yang tinggi yang akan memudahkan seseorang untuk mengubah prinsip dan perilaku dalam menentukan pilihan kontrasepsi yang terbaik bagi dirinya. AKDR berbeda dengan kontrasepsi lainnya; oleh karena itu jenjang pendidikan responden yang tinggi merupakan transmisi pengetahuan atau proses membangun manusia menjadi berpendidikan.

\section{SIMPULAN}

Pada akseptor KB aktif di Puskesmas Jailolo 27 Desember 2012-19 Januari 2013, faktor usia, pendidikan, pengetahuan, tarif pelayanan, persetujuan pasangan, dan budaya mempunyai hubungan dengan pemilihan AKDR; dan yang paling berperan ialah faktor pendidikan.

\section{SARAN}

Pelayanan kesehatan lebih ditujukan untuk memberikan KIE (Komunikasi, Informasi dan Edukasi) bagi masyarakat, khususnya akseptor KB, sehingga kontrasepsi AKDR lebih diminati sebagai kontrasepsi yang efektif dan aman.

\section{UCAPAN TERIMA KASIH}

Ucapan terima kasih ditujukan kepada Dr. Werna Nontji, S. Kp. M. Kep dan Ester Hutagaol, M. Kep. Sp. Mat selaku penguji dan semua pihak baik secara langsung maupun tidak langsung telah menumbuhkan ide dan memberi gagasan sehingga penulisan artikel ini dapat terlaksana.

\section{DAFTAR PUSTAKA}

1. KOMPAS [homepage on the Internet]. 2012 [Diakses 2012 November 10]. Available from: http://www.depdagri.go.id/news/2012/09/1 9/jumlah-penduduk-indonesia-.

2. Arum DN. S. Sujiyatini. Panduan Lengkap Pelayanan KB Terkini. Jokjakarta: Nuha Medika, 2011.

3. Handayani S. Buku Ajar Pelayanan Keluarga Berencana. Yokyakarta: Pustaka Rihama, 2010.

4. Riyanto A. Aplikasi Metodologi Penelitian Kesehatan. Yokyakarta: Nuha Medika, 2011.

5. Sunyoto D. Analisis untuk Penelitian Kesehatan. Yokyakarta: Nuha Medika, 2011.

6. Notoatmodjo. Kesehatan Masyarakat Ilmu dan Seni. Jakarta: Rineka Cipta, 2007.

7. Kriebs JM \& Gegor CL. Buku saku Asuhan Kebidanan Varney (Edisi Kedua). Jakarta: EGC, 2009. 